\title{
STATISTICAL ANALYSIS OF THE SPATIAL RELATIONSHIP OF CAATINGA AND PHYSIOGRAPHIC FACTORS THROUGH REMOTE DATA
}

\author{
Janisson Batista de Jesus ${ }^{1 *}$, Mariana Mizutani Ribeiro², Tatiana Mora Kuplich ${ }^{3}$, Bruno Barros de \\ Souza $^{4}$, Dráuzio Correia Gama ${ }^{5}$ \\ ${ }^{1 *}$ Federal University of Rio Grande do Sul, Postgraduate Program in Remote Sensoring-PPGSR, Porto Alegre, state of Rio \\ Grande do Sul, Brazil - janisson.eng@gmail.com \\ ${ }^{2}$ Federal University of Rio Grande do Sul, Postgraduate Program in Remote Sensoring-PPGSR, Porto Alegre, state of Rio \\ Grande do Sul, Brazil - marianamizutani@gmail.com \\ ${ }^{3}$ National Institute for Space Research, Santa Maria, state of Rio Grande do Sul, Brazil - tatiana.kuplich@inpe.br \\ ${ }^{4}$ Institute of Environment and Water Resources of the State of Bahia, Chapada Diamantina Regional Unit, state of Bahia, \\ Brazil - brunobarros.eco@gmail.com \\ ${ }^{5}$ State University of the Southwest of Bahia, Postgraduate Program in Forest Sciences, Vitória da Conquista, state of Bahia, \\ Brazil - drauziogama@hotmail.com
}

Received for publication: 20/03/2018 - accepted for publication: 02/08/2018

\begin{abstract}
Resumo
Análise estatística da relação espacial da caatinga e fatores fisiográficos através de dados remotos. A caatinga é característica do semiárido do Brasil, de significativa abrangência no nordeste do país e, por isso, técnicas de geoprocessamento e estatística podem ser importantes ferramentas para analisar os fatores ambientais associados a sua distribuição. O presente estudo teve o objetivo de analisar a relação da: altimetria, declividade, tipo de solo e proximidade do rio na distribuição espacial da vegetação de caatinga, utilizando uma base de dados gerada por técnicas de geoprocessamento. Foi utilizado o NDVI, e a análise estatística foi baseada na regressão múltipla e a correlação de Pearson. Os resultados mostram que a estação climática é a única variável que apresentou um coeficiente de determinação alto com a vegetação de caatinga $(R 2=0,956)$, enquanto as demais variáveis independentes tem fraca ou inexistente correlação. As técnicas de geoprocessamento permitiram observar que a Caatinga tem uma distribuição espacial generalista de ocorrência, não tendo um padrão definido.
\end{abstract}

Palavras-chave: floresta seca, NDVI, sensoriamento remoto, múltiplas variáveis.

\begin{abstract}
The caatinga is characteristic of the semi-arid region of Brazil, of significant coverage in the northeast of the country and, therefore, geoprocessing and statistical techniques can be important tools to analyze the environmental factors associated with its distribution. The present study had the objective of analyzing the relationship of: altimetry, slope, soil type and river proximity in the spatial distribution of the caatinga vegetation, using a database generated by geoprocessing techniques. NDVI was used, and statistical analysis was based on multiple regression and Pearson's correlation. The results show that the weather station is the only variable that presented a high determination coefficient with the caatinga vegetation $(R 2=0.956)$, while the other independent variables have weak or nonexistent correlation. With the techniques of geoprocessing was allowed to observe that the Caatinga has a generalist spatial distribution of occurrence, not having a defined pattern.

Keywords: dry forest, NDVI, remote sensing, multiple variables.
\end{abstract}

\section{INTRODUCTION}

Caatinga vegetation, although occurring predominantly in the Northeast, is endemic to Brazil and covers $10 \%$ of the national territory. Therefore, it is still a poorly studied environment, especially in relation to remote sensoring vegetation techniques (BEZERRA et al., 2012). Even so, the use of these technologies focusing on the analysis of caatinga's vegetation characteristic through vegetation indexes is increasing, especially through Normalized Difference Vegetation Index (NDVI) (AQUINO et al., 2016; JESUS; SANTANA, 2017).

Studies that involve vegetation distribution or isolated species observed in the published research cover their different types of associations, but do not cover the different variables that may influence their spatialization. Only the study conducted by Terra et al. (2015) analyzed the influence of multiple factors on the vegetation of an Atlantic Forest fragment in the Serra da Mantiqueira, state of Minas Gerais, addressing statistical techniques, but

FLORESTA, Curitiba, PR, v. 49, n. 4, p. 755 - 762, out/dez 2019.

Jesus, J. B. et.al.

ISSN eletrônico 1982-4688 
without using remote sensoring techniques. However, some studies have already been using these techniques, especially NDVI, to associate vegetation with the various environmental factors (FIGUEIREDO et al., 2015; GAIDA et al., 2016), but without focusing on statistical correlations, especially at a multifactorial level with emphasis on caatinga vegetation. Regarding this, it is possible to mention only the study of Bishop et al. (2010), who studied the relationship of this type of forest to the geomorphometric condition through discriminant analysis in the Natural Reserve of Serra das Almas, state of Ceará.

In order to analyze the various factors that may influence the characteristics of a study object, it is important to use statistical methods that can describe and analyze data from many correlated variables, assuming that they explain the complexity of a biological system (NASCIMENTO et al., 1997). From this, the multivariate analysis is presented aiming to analyze together variables that are experimentally correlated (MACHADO et al., 2014).

Thus, the present study had the objective of analyzing the relationship of environmental varibles set (altimetry, slope, soil type and river proximity) in the spatial distribution of the caatinga vegetation, using a database generated by geoprocessing techniques. In order to do so, the following hypotheses were adopted: a) caatinga presents positive correlation with the proximity of water bodies, presenting higher values of NDVI in the regions near the river; b) it presents a negative correlation with the variation of slope and altimetry; c) the soil type affects the vegetation expression in the studied area.

\section{MATERIAL AND METHODS}

\section{Area of study}

The study was carried out in the State Conservation Unit Grota do Angico Natural Monument, located between the coordinates UTM X/Y: 637270.59/8935547.258 m and 649298.966/8925786.101 m, Datum SIRGAS 2000, covering the municipalities of Canindé de São Francisco and Poço Redondo in the northwest of the state of Sergipe, in which the São Francisco River is located in north as divisor to the state of Alagoas. It has a total area of 2,138 ha, composed of dense tree hyperxerophytic caatinga (SERGIPE, 2007) with the climate of type Bssh' by the classification of Koppen, with very hot, semi-arid, steppe type characteristics (SOUSA et al., 2014).

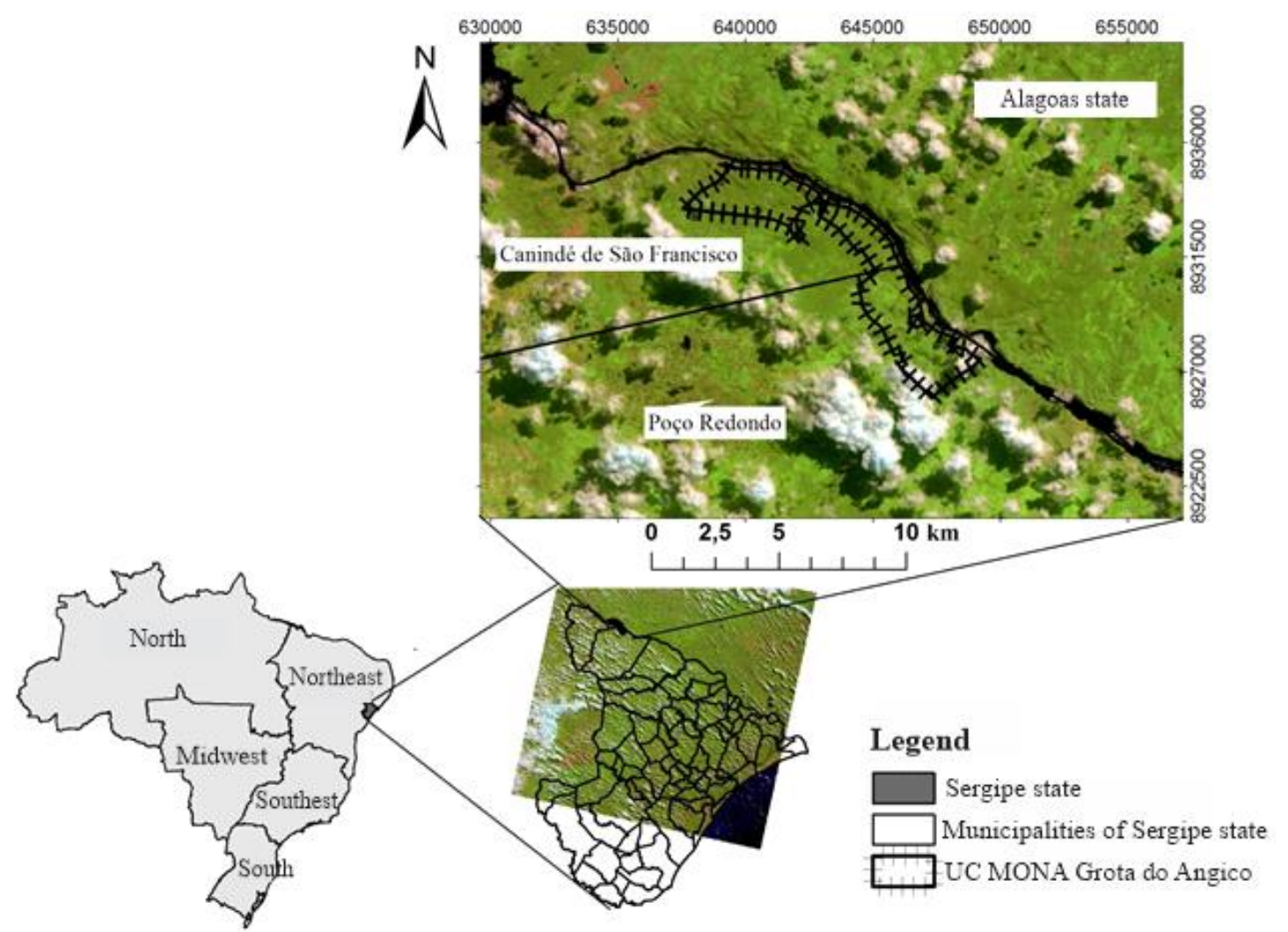

Figura 1. Localização da área de caatinga estudada (Landsat-8 falsa cor RGB: 6-5-3).

Figure 1. Location of the area of the caatinga studied (fake color Landsat-8 RBG: 6-5-3). 


\section{Obtaining the data}

The vegetation data were obtained from Landsat-8 satellite OLS/TIRS sensor images, level 1. Two scenes were acquired directly by the website of the United States Geological Survey (USGS, 2017), one referring to the rainy season (July 14, 2017) in order to have high vegetation expression and another during the dry season (January 3 , 2017) with cumulative precipitation from the previous month up to the date of the image of 182.0 and $0.0 \mathrm{~mm}$ (INPE, 2017), respectively, to observe the behavior of vegetation in water deficit. The images' time were chosen with the objective of verifying if there is a relation of the areas with greater vegetation in relation to the environmental variables analyzed during the seasonal variation, and in agreement with the smaller amount of clouds in the studied area.

After the acquisition of the images, the images pre-processing was performed, since they do not have surface reflectance. For this, the Semi-Automatic Classification Plugin (SCP) was used, using the atmospheric correction method Dark Object Subtraction 1 (DOS1) using QGIS software 2.18 (GÉMES et al., 2016).

The vegetation data were obtained pixel by pixel by means of band algebra via vegetation index, using NDVI (NIR-R/NIR+R), which considers bands 4 and 5 of the Landsat- 8 satellite, respectively of red ( $R=0.64$ to $0.67 \mu \mathrm{m})$ and near-infrared ( $\mathrm{NIR}=0.85$ to $0.88 \mu \mathrm{m}$ ), subsequently excluding regions affected by clouds and shadows during the rainy season, and associating larger caatinga to the highest values of NDVI based on the studies of Francisco et al. (2015) and Aquino et al. (2016).

The values related to altimetry, slope, soil type and proximity of the São Francisco River were obtained from the Digital Atlas of Water Resources of the State of Sergipe (SEMARH, 2012), which includes the geospatial data already mapped throughout the state. For the altimetry data, the digital elevation model was generated from the $10 \mathrm{~m}$ level curves and later used to calculate the slope of the terrain in percentage. The distance from the river was calculated from the previously generated raster conversion, converting each pixel into points and then applying the near function, which calculates the smallest linear distance between two features, the second feature being the shape itself of the São Francisco River.

This technique of converting raster-point was used in the other variables in order to obtain, for each pixel, its assigned value, taking into account the matrix of $30 \times 30 \mathrm{~m}$ to be compatible with the spatial resolution of Landsat-8 and finally generate a database for both periods (rainy and dry) with the information associated with the same pixel for each analyzed variable, which is exported in Excel spreadsheets for later statistical analysis.

\section{Statistical analysis}

Statistical calculations were performed in the application of multiple regression and Pearson correlation, with NDVI related to the other variables (slope, altimetry, river proximity and soil type) considered as independent and explanatory factors, as well as the season (dry vs. rainy).

Multiple regression was performed using the forward method of variable selection that includes the explanatory variables one by one, according to their order of importance for the explanation of the dependent variable (NDVI), until no variable presents a significant increase in the explanation of the variable answer. In this analysis, the environmental factors (altimetry, slope, soil type and distance of the river) were considered and a temporal factor that indicates in which season the indicator was measured (dry season and rainy season). In all, 19,042 points (n) were analyzed in each of the images.

Statistical processing of the data together with the analysis and interpretation of the generated results was carried out in SPSS software at the Mathematical Institute, Department of Statistics of the Federal University of Rio Grande do Sul - UFRGS.

\section{RESULTS}

The analyzed area presents an altimetric variation of $180 \mathrm{~m}$, a slope of 0 to $211 \%$, with the Litholic soil being the predominant one, with a small region of the type Bruno non-Calcium, a greater distance reaching 2,355.39 $\mathrm{m}$ in relation to the river San Francisco, with a maximum proximity of $1.87 \mathrm{~m}$. Regarding the value of NDVI, for the rainy season there was a variation of 0.66 to 0.88 . While for the dry period image ranged from 0.24 to 0.57 (Figure 2).

FLORESTA, Curitiba, PR, v. 49, n. 4, p. 755 - 762, out/dez 2019. 

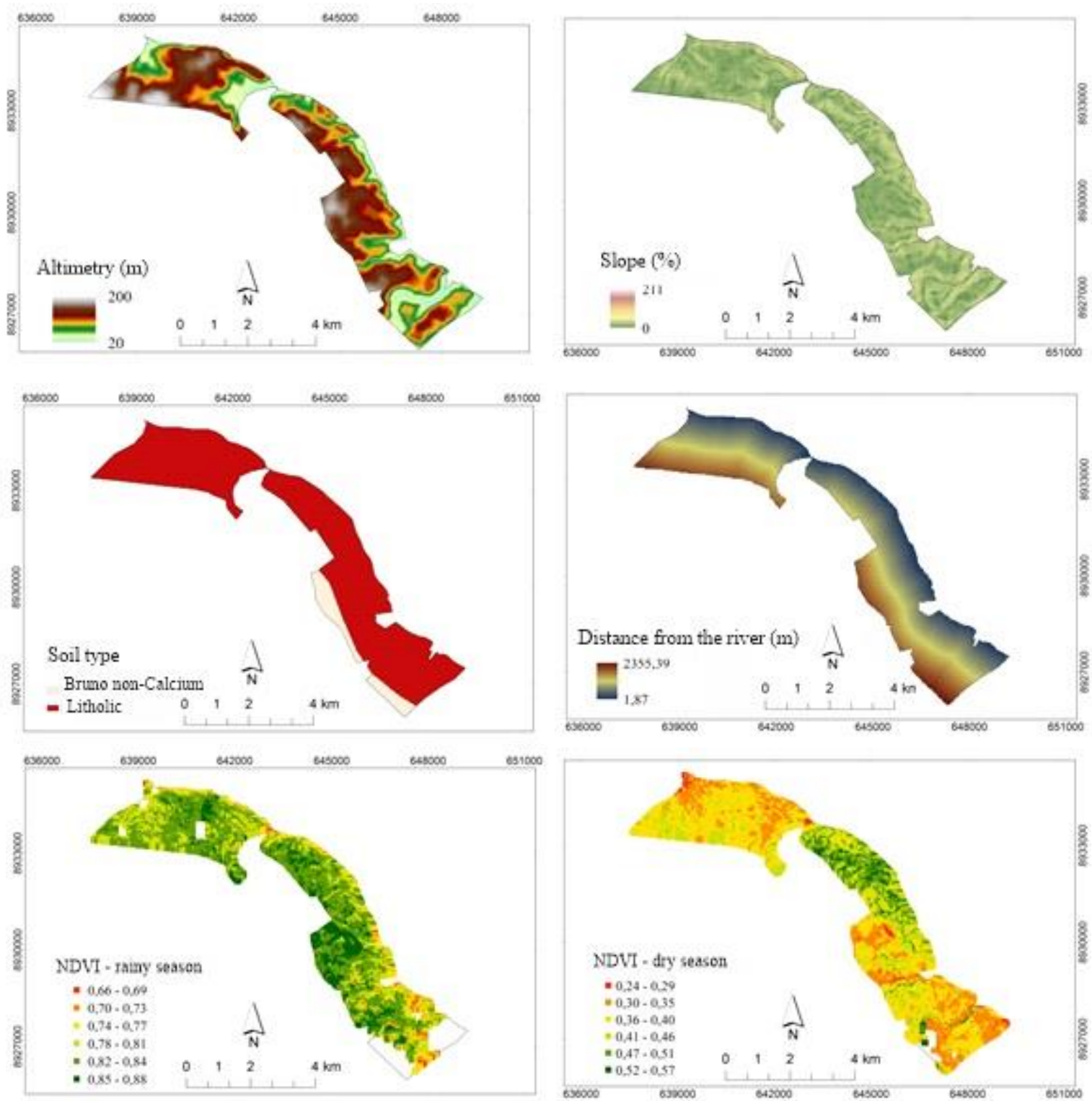

Figura 2. Distribuição espacial das variáveis: altimetria, declividade, tipo de solo, distância do rio, e NDVI referente ao período chuvoso e seco.

Figure 2. Spatial distribution of variables: altimetry, slope, soil type, proximity to the river, and NDVI for the rainy and dry season.

The forward method selected the variable station of the year for the first model generated and it has a $\mathrm{R}^{2}$ of approximately 0.956 associated with the vegetation (Table 1 ) evaluated through the NDVI. In addition, the inclusion of the other variables brought an unimpressive gain in the coefficient of determination with a maximum $\mathrm{R}^{2}$ of 0.957 , verifying that only the factors of the season, altimetry and distance of the river were significant, since the type factors of soil and slope were not included in subsequent selection steps.

Tabela 1. ANOVA do método forward.

Table 1. ANOVA of the forward method. 


\begin{tabular}{lccccccc}
\hline \multicolumn{7}{c}{ ANOVA } \\
\hline Models & & $\begin{array}{c}\text { Sum of the } \\
\text { Squares }\end{array}$ & $\begin{array}{c}\text { Degrees of } \\
\text { freedom }\end{array}$ & $\begin{array}{c}\text { Average } \\
\text { Square }\end{array}$ & F & Sig. & $\mathbf{R}^{\mathbf{2}}$ \\
\hline Constant + Season & Regression & $1,694.96$ & 1 & $1,694.96$ & $816,607.07$ & 0.000 & 0.956 \\
& Residue & 78.85 & 38,082 & 0.002 & & & \\
& Total & $1,773.81$ & 48.083 & & & & \\
\hline Constant + & Regression & $1,696.48$ & 2 & 848.241 & $417,713.87$ & 0.000 & 0.956 \\
Season+ Altimetry & Residue & 77.33 & 38.081 & 0.002 & & & \\
& Total & $1,773.81$ & 38.083 & & & & \\
\hline Constant + Season & Regression & $1,697.77$ & 3 & 565.923 & $283,396.73$ & 0.000 & 0.957 \\
+ Altimetry + & Residue & 76.04 & 38.080 & 0.002 & & & \\
$\begin{array}{l}\text { Distance from the } \\
\text { river }\end{array}$ & Total & $1,773.81$ & 38.083 & & & & \\
\hline
\end{tabular}

The values of Pearson's linear correlation of NDVI with continuous natural factors and factors between them show non-expressive values (Figure 3). The only explanatory variable that presented linear correlation with the NDVI was the altimetry in the rainy season expressed by a value of 0.37 . The analysis also indicates that there is no positive correlation of vegetation with the proximity of the São Francisco River, since the Pearson correlation value was -0.204 for dry season and 0.195 for rainy season. Among the independent variables, the most expressive relation among the natural factors evaluated presented a correlation value of 0.37 between the vegetation index and altimetry, and a positive relation (0.444) between altimetry and proximity to the water body.

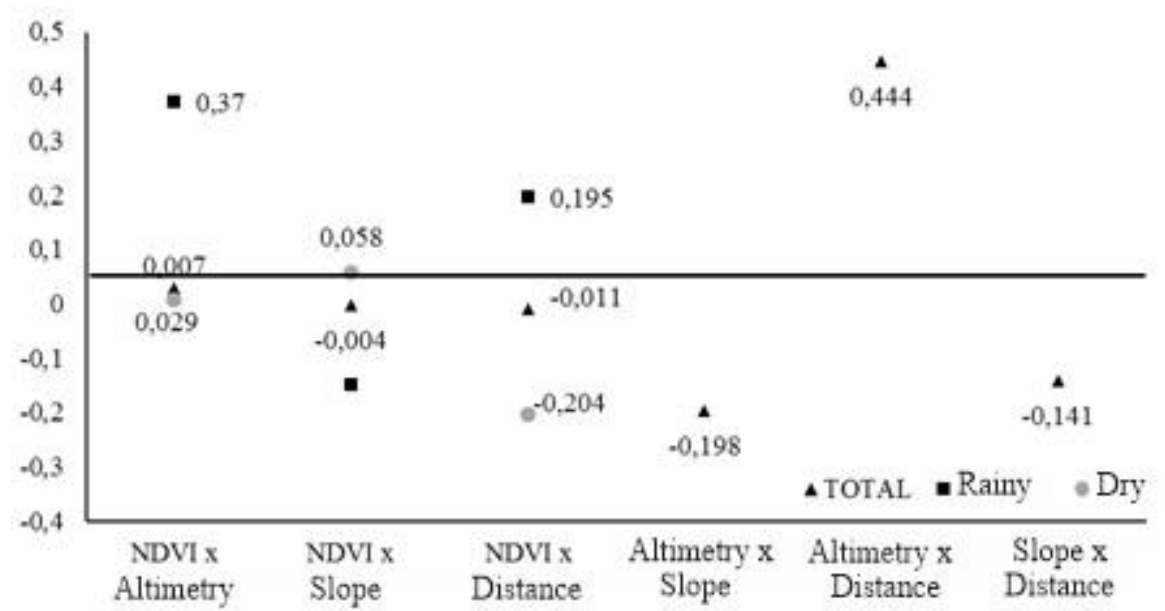

Figura 3. Gráfico de Correlação de Pearson entre as variáveis analisadas em função da estação chuvosa e seca.

Figure 3. Pearson Correlation chart between the variables analyzed in function of the rainy and dry season.

Evaluating the graphs of each factor of univariate form with the NDVI, it is observed that there is a tendency of correlation in both periods of the images for each variable, with the cloud of scattered points in relation to the axis of the correlative line causing redundancy in the relations, thus configuring a low linear trend (Figure 4). Despite the difference in vegetation responses to the rainfall regime, there are similarities in the dispersion of NDVI values for the factors, where in relation to both altimetry and the proximity of the river, there is a cloud spaced along its axis, while for declivity the points have a bottleneck to the increase of their percentage. 

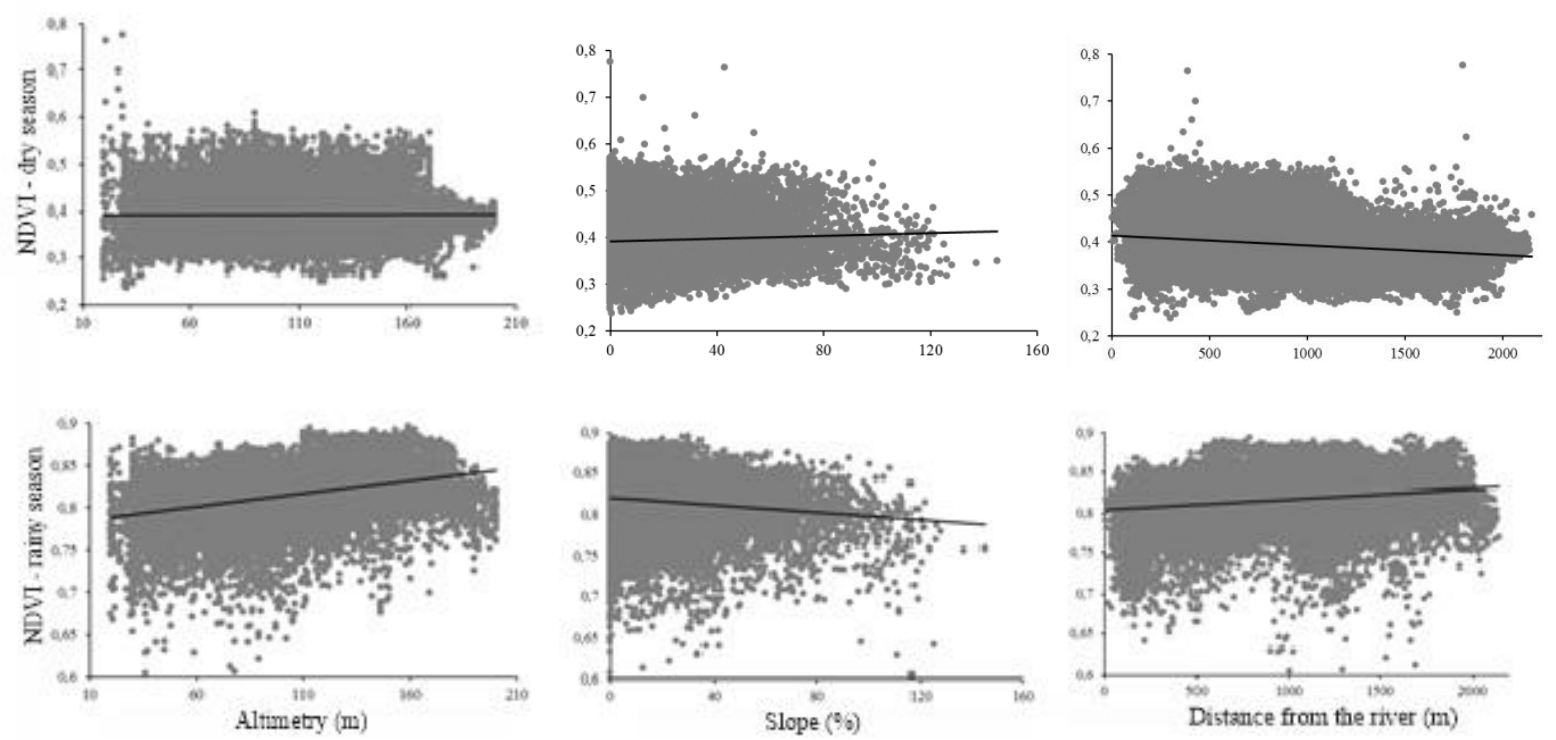

Figura 4. Correlações lineares univariadas entre o NDVI (estação chuvosa e seca) e as variáveis valoradas analisadas (altimetria, declividade e distância do rio).

Figure 4. Univariate linear correlations between the NDVI (rainy and dry season) and the valued variables analyzed (altimetry, slope and distance from the river).

In addition, the trend lines behave differently for the variables in both periods, meaning that in the rainy season there is a smaller slope of the line, which is larger for the NDVI results as a function of altimetry and slope. Meanwhile in the dry season practically no slope is observed for these factors, which characterizes the lack or nonexistence of correlation between the analyzed variables.

\section{DISCUSSION}

Associating the highest values of NDVI to a greater size of the caatinga vegetation (FRANCISCO et al., 2015; AQUINO et al., 2016), that is to say, a tree phytophysiognomy and, therefore, greater biomass, it is verified that there is no correlation of the multifactors with the spatial distribution of the different forms of this vegetation.

The statistical analysis obtained by the forward method shows that only the pluviometric regime influences significantly in the response of the caatinga vegetation in the studied area, indicating that the variation of the NDVI and, consequently of the vegetation, is related only to the season of the year in which it is observed, and that there is no linear correlation of the indicator with the other analyzed variables. This relation is consistent with the results of Santos et al. (2017) that associated precipitation with the NDVI response of the caatinga at different times.

This low correlation between the environmental variables and NDVI was also confirmed by the Pearson correlation, which indicated a weak linear relationship between the factors, except for the NDVI and altimetry for the rainy season, which showed a more expressive value, which was also seen by Santos et al. (2016) when analyzing the NDVI along a topographic profile, where they observed a vegetation variation response, noting high values of this index associated with high altitudes. And by Pereira et al. (2012) who also obtained a positive association between NDVI and altimetry, verifying that the densest caatinga vegetation was related to the areas of higher altitudes.

In the caatinga distribution evaluation with the slope and with the soil it is noted that there is a lack of linear relation between the two variables in the studied area. However, Maçuana et al. (2016a; 2016b) noted that elevation and slope were the most important predictors of floristic variations in subtropical forest under the Atlantic Forest. Souza et al. (2012) also concluded that changes in chemical fertility, soil acidity and texture along the topographic gradient influenced the distribution of the species in a fragment of Submontane Semidecidual Seasonal Forest. Zanzarini et al. (2013) reported that soil attributes presented a spatial correlation as NDVI for sugarcane agricultural production. Souza et al. (2013) also verified that the geomorphologic gradient influences the structural variation of the Submontane Semideciduous Seasonal Forest. This shows that although the NDVI does not present significant correlation to these variables as well as to the soil, there may be a variation in the structure and floristic 
composition in the studied caatinga area, since its pattern of spatial distribution occurs with most species presenting aggregate distribution and the largest populations forming small clusters (SANTANA et al., 2016).

Despite the fact that the weak or non-existent correlation of the vegetation index in relation to the other factors indicates a generalist distribution of the caatinga, it is pointed out that this result can also be affected by the environmental degradation in the area that despite being a Conservation Unit, it had anthropic influence in their territory.

\section{CONCLUSIONS}

- The statistical analysis proved to be an important tool to be used for comparisons of multiple variables applied to vegetation, as well as the use of geoprocessing techniques to obtain spatial and biophysical data of the caatinga vegetation.

- The vegetation of the caatinga does not have a spatial pattern defined from the physiographic characteristics of the studied area, discarding the hypotheses that this type of forest presents higher values of NDVI in the regions closer to the São Francisco River. Moreover, there is no negative correlation between vegetation index using declivity and altimetry, reflecting in a weak or nonexistent correlation between these variables. The soil type also did not influence the caatinga distribution in the study region.

\section{ACKNOWLEDGEMENT}

The first author thanks the Coordination for the Improvement of Higher Level Personnel (CAPES) for granting a PhD Scholarship.

\section{REFERENCES}

AQUINO, C.M.S.; VALLADARES, G.S.; AQUINO, R.P.; OLIVEIRA, J.G.B. Variação temporal do Índice de Vegetação por Diferença Normalizada-NDVI no Parque Nacional da Serra da Capivara e seu entorno, Piauí, Brasil. Revista de Geociências do Nordeste, Caicó, v. 2 (especial), p. 640 - 649, 2016.

BEZERRA, J.M.; VASCONCELOS, R.S.; MOURA, G.B. de A.; ESPÍNOLA SOBRINHO, J. Spectral indices of vegetation to caatinga of the area of semi-arid of Rio Grande of Norte, Brazil. Journal of Hyperspectral Remote Sensing, Recife, v. 2, n. 2, p. 10 - 24, 2012.

BISPO, P. da C.; VALERIANO, M. de M.; KUPLICH, T.M. Relação da vegetação de caatinga com a condição geomorfométrica local. Revista Brasileira de Engenharia Agrícola e Ambiental, Campina Grande, v. 14, n. 5, p. $523-530,2010$.

FIGUEIREDO, S.M. de M.; VENTICINQUE, E.M.; FIGUEIREDO, E.O.; FERREIRA, E.J.L. Predição da distribuição de espécies florestais usando variáveis topográficas e de índice de vegetação no leste do Acre, Brasil. Acta Amazonica, Manaus, v. 45, n. 2, p. 167 - 174, 2015. doi: http://dx.doi.org/10.1590/1809-4392201402834.

FRANCISCO, P.R.M.; CHAVES, I. de B.; CHAVES, L.H.G.; LIMA, E.R.V. de; SILVA, B.B. da. Análise espectral e avaliação de índices de vegetação para o mapeamento da caatinga. Revista Verde de Agroecologia e Desenvolvimento Sustentável, Pombal, v. $10, \quad$ n. $3, \quad$ p. $1 \quad-\quad 12, \quad 2015$. doi: http://dx.doi.org/10.18378/rvads.v10i3.3046.

GAIDA, W.; BREUNING, F.M.; GALVÃO, L.S.; TELES, T.S.; BALBINOT, R. Variações da reflectância e dos índices de vegetação em função dos parâmetros da modelagem topográfica no Parque Estadual do Turvo, Rio Grande do Sul, Brasil. Investigaciones Geográficas, Alicante, v. 91, p. 105 - 123, 2016. doi: http://dx.doi.org/10.14350/rig.52159.

GÉMES, O.; TOBAK, Z.; LEEUWEN, B. van. Satellite based analysis of surface urban heat island intensity. Journal of Environmental Geography, Szeged, v. 9, n. 1 - 2, p. 23 - 30. 2016. doi: 10.1515/jengeo-2016-0004.

INPE. Instituto de Pesquisas Espaciais. Sistema Integrado de Dados Ambientais. Disponível em: <http://sinda.crn2.inpe.br/PCD/SITE/novo/site/index.php> Acesso em: 16/09/2017.

JESUS, J.B. de; SANTANA, I.D.M. Estimation of land surface temperature in caatinga area using Landsat 8 data. Journal of Hyperspectral Remote Sensing, Recife, v. 7, n. 3, p. 150 - 157, 2017. doi: https://doi.org/10.29150/jhrs.v7i3.22766. 
MACHADO, S.T.; SANTOS, R.C.; CALDARA, F.R.; GONÇALVES, M.C.; NÄÄS, I. de A. Integrated multivariate analysis to evaluate effects of preslaughter handling on pork quality. Engenharia Agrícola, Jaboticabal, v. 34, n. 3, p. 435 - 444, 2014. doi: http://dx.doi.org/10.1590/S0100-69162014000300007.

MAÇANEIRO, J.P. de; SEUBERT, R.C.; SCHORN, L.A. Variações na composição e estrutura da vegetação permitem detectar agrupamentos florísticos em uma Floresta Subtropical Atlântica no Sul do Brasil? Biotemas, Florianópolis, v. 29, n. 4, p. 43 - 58, 2016a. doi: http://dx.doi.org/10.5007/2175-7925.2016v29n4p43.

MAÇANEIRO, J.P. de; OLIVEIRA, L.Z.; SEUBERT, R.C.; EISENLOHR, P.V.; SCHORN, L.A. More than environmental control at local scales: do spatial processes play an important role in floristic variation in subtropical forests? Acta Botanica Brasilica, Belo Horizonte, v. 30, n. 2, p. 183 - 192, 2016b. doi: 10.1590/0102$33062015 \mathrm{abb} 0294$.

NASCIMENTO, C.G. do; GARCIA, J.N.; DIÁZ, M. del P. Agrupamento de espécies madeireiras da Amazônia em função da densidade básica e propriedades mecânicas. Madera y Bosques, Xalapa, v. 3, n. 1, p. 33 - 52, 1997.

PEREIRA, J.A. dos S.; FRANÇA, L.M. de A.; GALVÍNCIO, J.D. Relationship between vegetation indices and altimetry in Triunfo-PE, Brazil. Journal of Hyperspectral Remote Sensing, Recife, v. 2, n. 3, p. 37 - 43, 2012.

SANTANA, J.A. da S.; SANTANA JÚNIOR, J.A. da S.; BARRETO, W. da S.; FERREIRA, A.T. da S. Estrutura e distribuição espacial da vegetação da Caatinga na Estação Ecológica do Seridó, RN. Pesquisa Florestal Brasileira, Colombo, v. 36, n. 88, p. 355 - 361, 2016. doi: 10.4336/2016.pfb.36.88.1002

SANTOS, L.S; SILVA, H.P.B.; PEREIRA, E.C.G.; CABRAL, C.J.; SILVA, J.C.B. Perfil de paisagem entre os municípios de Águas Belas e Saloá (Pernambuco - Brasil), com ênfase na cobertura vegetal. Revista de Geociências do Nordeste, Caicó, v. 2 (especial), p. 991 - 1000, 2016.

SEMARH. Atlas digital sobre recursos hídricos de Sergipe. Sistema de informações sobre recursos hídricos de Sergipe. Superintendência de Recursos Hídricos do Estado de Sergipe, versão 2012.9.

SERGIPE. Decreto Estadual $\mathbf{n}^{\circ}$ 24.922, de 21 de dezembro de 2007. Cria o Monumento Natural Grota do Angico, nos Municípios de Poço Redondo e Canindé de São Francisco, Estado de Sergipe, e dá outras providências. Disponível em: >http://acervo.se.gov.br/easysearch/\#q=24.922> Acesso em: 10 ago 2016.

SANTOS, C.V.B.; BAPTISTA, G.M.M.; MOURA, M.S.B. Seasonality of Vegetation Indices in different land uses in the São Francisco Valley. Journal of Hyperspectral Remote Sensing, Recife, v. 7, n. 3, p. 158 - 167, 2017. doi: https://doi.org/10.29150/jhrs.v7i3.25345.

SOUZA, P.B. de; LELIS, J.J.; SCHAEFER, C.E.G.R.; SOUZA, A.L. de; MEIRA NETO, J.A.A. Distribution of tree species in a geomorphological and pedological gradient of submontane semidecidual seasonal forest in the Vicinity of Rio Doce State Park, Minas Gerais. Revista Árvore, Viçosa, v. 36, n. 4, p. 707 - 718, 2012.

SOUZA, P.B. de; MEIRA NETO, J.A.A.; SOUZA, A.L. de. Diversidade florística e estrutura fitossociológica de um gradiente topográfico em Floresta Estacional Semidecidual Submontana, MG. CERNE, Lavras, v. 19, n. 3, p. 489 - 499, 2013.

SOUSA, I.F. de; AGUIAR NETTO, A. de O.; SILVA, B.B. da. Balanço de radiação e energia no perímetro irrigado Califórnia-SE mediante imagens orbitais. Revista Brasileira de Geografia Física, Recife, v. 7, n. 6, p. 1165 - 1172, 2014.

TERRA, M. de C.N.S.; MELLO, J.M. de; MELLO, C.R. de; SANTOS, R.M. dos; NUNES, A.C.R.; RAIMUNDO, M.R. Influência topo-edafo-climática na vegetação de um fragmento de Mata Atlântica na Serra da Mantiqueira, MG. Ambiente \& Água, Taubaté, v. 10, n. 4, p. 928 - 942, 2015. doi: 10(4): 928-942.10.4136/ambi-agua.1705.

USGS. LANDSAT 8. Disponível em: <https://landsat.usgs.gov/Landsat8_Using_Product.php> Acesso em: $16 / 09 / 2017$

ZANZARIRI, F.V.; PISSARRA, T.C.T.; BRANDÃO, F.J.C.; TEIXEIRA, D.D.B. Correlação espacial do índice de vegetação (NDVI) de imagem Landsat/ETM+ com atributos do solo. Revista Brasileira de Engenharia Agrícola e Ambiental, Campina Grande, v. 17, n. 6, p. 608 - 614, 2013. 